\title{
Systematic Review
}

\section{Occlusal Scheme Effect on the Biomechanical Response of Full-Arch Dental Prosthesis Supported by Titanium Implants: A Systematic Review}

\author{
Laís Carolina Landim Gomes ${ }^{1,+}$, Fernanda Zapater Pierre ${ }^{1,+}+\mathbb{0}$, João Paulo Mendes Tribst ${ }^{2, *} \mathbb{C}^{\circ}$, \\ Nathália de Carvalho Ramos ${ }^{3}$ (1), Eduardo Bresciani ${ }^{4}$, Rodrigo Máximo de Araújo ${ }^{1}$, Lafayette Nogueira Júnior ${ }^{1}$ \\ and Marco Antonio Bottino ${ }^{1}$ \\ 1 Department of Dental Materials and Prosthesis, Institute of Science and Technology, \\ São Paulo State University (UNESP), São José dos Campos 12245-000, SP, Brazil; \\ landim.gomes@unesp.br (L.C.L.G.); fernanda.pierre@unesp.br (F.Z.P.); maximo.araujo@unesp.br (R.M.d.A.); \\ lafayette.nogueira-junior@unesp.br (L.N.J.); marco.bottino@unesp.br (M.A.B.) \\ 2 Department of Dentistry, University of Taubaté (UNITAU), Taubaté 12020-340, SP, Brazil \\ 3 College of Dentistry, São Francisco University (USF), Bragança Paulista 12916-220, SP, Brazil; \\ nathalia.carvalhoramos@gmail.com \\ 4 Department of Restorative Dentistry, Institute of Science and Technology, São Paulo State \\ University (UNESP), São José dos Campos 12245-000, SP, Brazil; eduardo.bresciani@unesp.br \\ * Correspondence: joao.tribst@gmail.com \\ $\dagger$ Co-first author, these authors contributed equally to this work.
}

check for updates

Citation: Gomes, L.C.L.; Pierre, F.Z.; Tribst, J.P.M.; Ramos, N.d.C.;

Bresciani, E.; de Araújo, R.M.; Júnior, L.N.; Bottino, M.A. Occlusal Scheme Effect on the Biomechanical Response of Full-Arch Dental Prosthesis Supported by Titanium Implants: A Systematic Review. Metals 2021, 11, 1574. https://doi.org/10.3390/met 11101574

Academic Editor: Takayoshi Nakano

Received: 26 August 2021

Accepted: 27 September 2021

Published: 2 October 2021

Publisher's Note: MDPI stays neutral with regard to jurisdictional claims in published maps and institutional affiliations.

Copyright: (c) 2021 by the authors. Licensee MDPI, Basel, Switzerland. This article is an open access article distributed under the terms and conditions of the Creative Commons Attribution (CC BY) license (https:/ / creativecommons.org/licenses/by/ $4.0 /)$.

\begin{abstract}
Dental implant-supported prosthesis are widely used in oral reconstruction of totally edentulous patients. Nonetheless, one of the most common failures in these cases is caused by overloading from improper occlusion. The aim of this work was to determine if the occlusal scheme influences the biomechanical response in implant-supported dental prostheses. Searches were conduct is several databases (PubMed/MEDLINE, The Cochrane Library, Web of Science, Scopus, LILACS, and Opengrey). We found 632 publications and 521 studies remained after removing duplicates. After applying the inclusion criteria, five studies were used in this systematic review: one clinical trial, one retrospective clinical trial, one in vitro and two in silico. The results show the lack of clinical and laboratory studies about occlusion in implant-supported prostheses. Although there are several studies regarding implant occlusion schemes, there remains a lack of scientific evidence to support that one specific occlusal scheme is superior to another, or to help define the ideal occlusal scheme that improves the clinical outcome. It can be concluded, however, that the proper distribution of loads and the absence of occlusal interferences can increase implant longevity. Thus, more clinical and laboratory studies must be carried out to obtain an occlusal scheme that favors the clinical success of implant rehabilitation.
\end{abstract}

Keywords: dental implants; dental occlusion; occlusal scheme; biomechanical response; prosthesis failure; mouth rehabilitation

\section{Introduction}

Since 1982, at the Toronto Conference on Osseointegration in Clinical Dentistry, a new possibility of treatment with edentulous patients was accepted with the proof of the effectiveness of integrated bone implants [1,2]. Thenceforth, dental implant-supported prosthesis have been extensively used for oral reconstruction of partial and complete edentulism. However, even with high success rates, late implant failures are mainly caused by peri-implantitis and occlusal overloading, resulting from improper occlusion [3-5]. Overloading creates stress around the implant components and bone-implant interface that is not biologically acceptable [5]. Dental implants frequently suffer from occlusal overload because the prostheses lack the supporting periodontal ligaments that are known 
to provide the shock-absorbing function of natural teeth [6]. Occlusal overload can cause mechanical complications, such as screw loosening and fractures, both in the prosthesis and in the implant itself, eventually compromising the longevity of the treatment [7]. The scientific literature has reported that the clinical success and longevity of dental implants can be achieved by biomechanically controlled occlusion [6,8]. It is important for all clinicians to know how occlusal force (normal or excessive), may influence implant successful rates. The ideal implant occlusion would allow controlled stress around the implant components, provide a prosthetic and biological acceptable bone-implant interface and obtain long-term stability of the marginal bone and prosthesis [9]. Studies that cite balanced occlusion concepts and recommendations are generally from natural dentition or conventional complete dentures. Few articles are found in the literature discussing ideal occlusion in implants, especially with total rehabilitation $[10,11]$. There is a lack of studies in the literature that provided theories or protocols on implant occlusion, few of them provided strong evidence about occlusion stability for dental implant. Thereby, the aim of this systematic review was to determine, even with the limitations in the literature, if the occlusal scheme influences the biomechanical response in full implantsupported prostheses.

\section{Materials and Methods}

\subsection{Protocol Registration}

This review was performed according to the Preferred Reporting Items for Systematic Reviews and Meta-analyses (PRISMA) 2020 guidelines [12] and registered at the International Prospective Register of Systematic Reviews-University of York (PROSPERO) ID: CRD42021249350.

\subsection{Focus Question}

The focus question PICO was: Does the occlusal scheme influence the biomechanical response in dental prosthesis implant-supported? (The question was as broad as possible to reach the largest number of articles). It was formulated considering the following four elements:

- Population (patients)—Dental implants/dental prosthesis, implant supported/ edentulous mouth;

- Intervention-occlusal scheme/dental occlusion/Implant-protected occlusion/ occlusal stability;

- Comparison-none;

- Outcome-dental stress distribution/ mouth rehabilitation.

\subsection{Literature Search}

The review was carried out from March to August 2021 (respecting the monthly alerts received with the update of newly published articles). Electronic searches were performed in the following databases: PubMed/MEDLINE, The Cochrane Library, Web of Science, Scopus, LILACS, and Opengrey. The research covered the languages English, Spanish and Portuguese, and had no restrictions regarding the period of publication or type of article.

The search used the Medical Subject Headings (MeSH) terms with several combinations and adapted according to each database specification. The search strategy is shown in Table 1. The condition (disease or healthcare) studied was focused on occlusal schemes and biomechanical response on dental implant prosthesis, in agreement with the following inclusion and exclusion criteria:

- Inclusion: Dental rehabilitation with titanium implant, Implant-protected occlusion, edentulous mouth, full-arch rehabilitation.

- Exclusion: Rehabilitation without dental implant. Single implant rehabilitation. 
Table 1. Algorithms for electronic searches in databases.

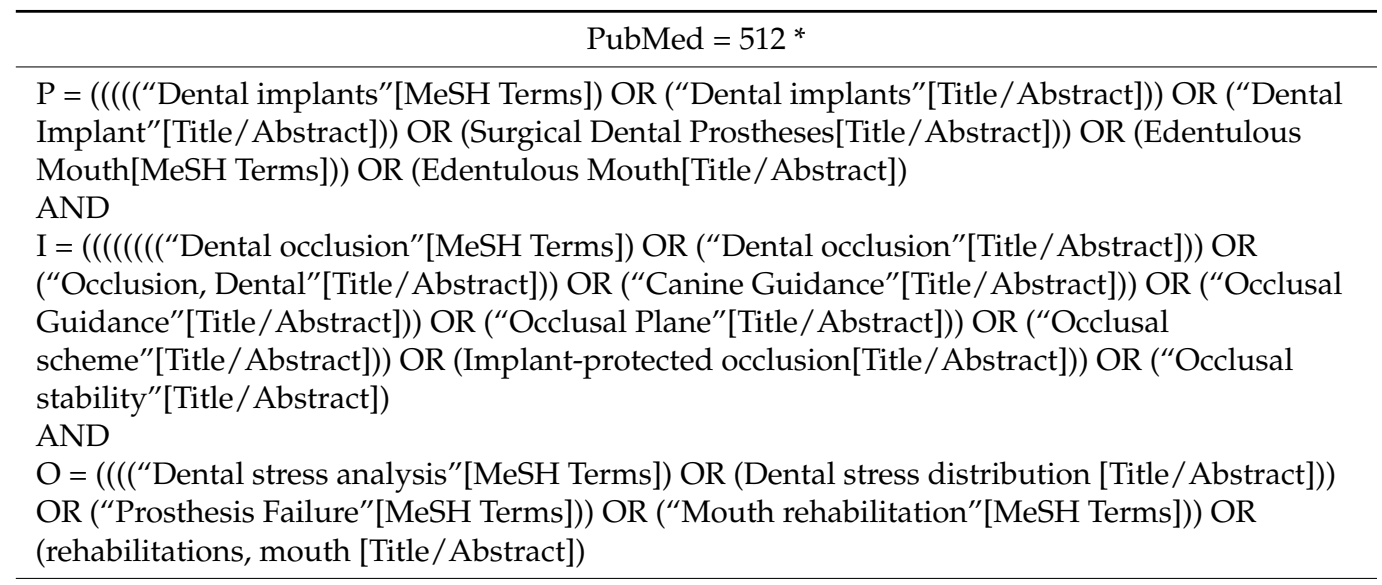
Scopus $=111$

TITLE-ABS-KEY (“Dental implants" OR “Dental Implant” OR “Surgical Dental Prostheses” OR “Edentulous Mouth"))

AND

(TITLE-ABS-KEY ("Dental occlusion" OR “Occlusion, Dental” OR “Canine Guidance” OR “Occlusal Guidance" OR “Occlusal Plane" OR "Occlusal scheme" OR "Implant-protected occlusion" OR "Occlusal stability"))

AND

(TITLE-ABS-KEY ("Dental stress analysis" OR “Dental stress distribution" OR "Prosthesis Failure" OR "Mouth rehabilitation" OR "rehabilitations, mouth"))

\section{Web of Science $=3$}

TS = ("Dental implants" OR “Dental implants" OR “Dental Implant" OR “Surgical Dental Prostheses" OR “Edentulous Mouth" OR “Edentulous Mouth")

AND

TS = ("Dental occlusion" OR “Occlusion, Dental" OR "Canine Guidance" OR “Occlusal Guidance" OR “Occlusal Plane" OR “Occlusal scheme" OR "Implant-protected occlusion" OR "Occlusal stability")

AND

TS = ("Dental stress analysis" OR "Dental stress distribution" OR "Prosthesis Failure" OR "Mouth rehabilitation" OR "rehabilitations, mouth")

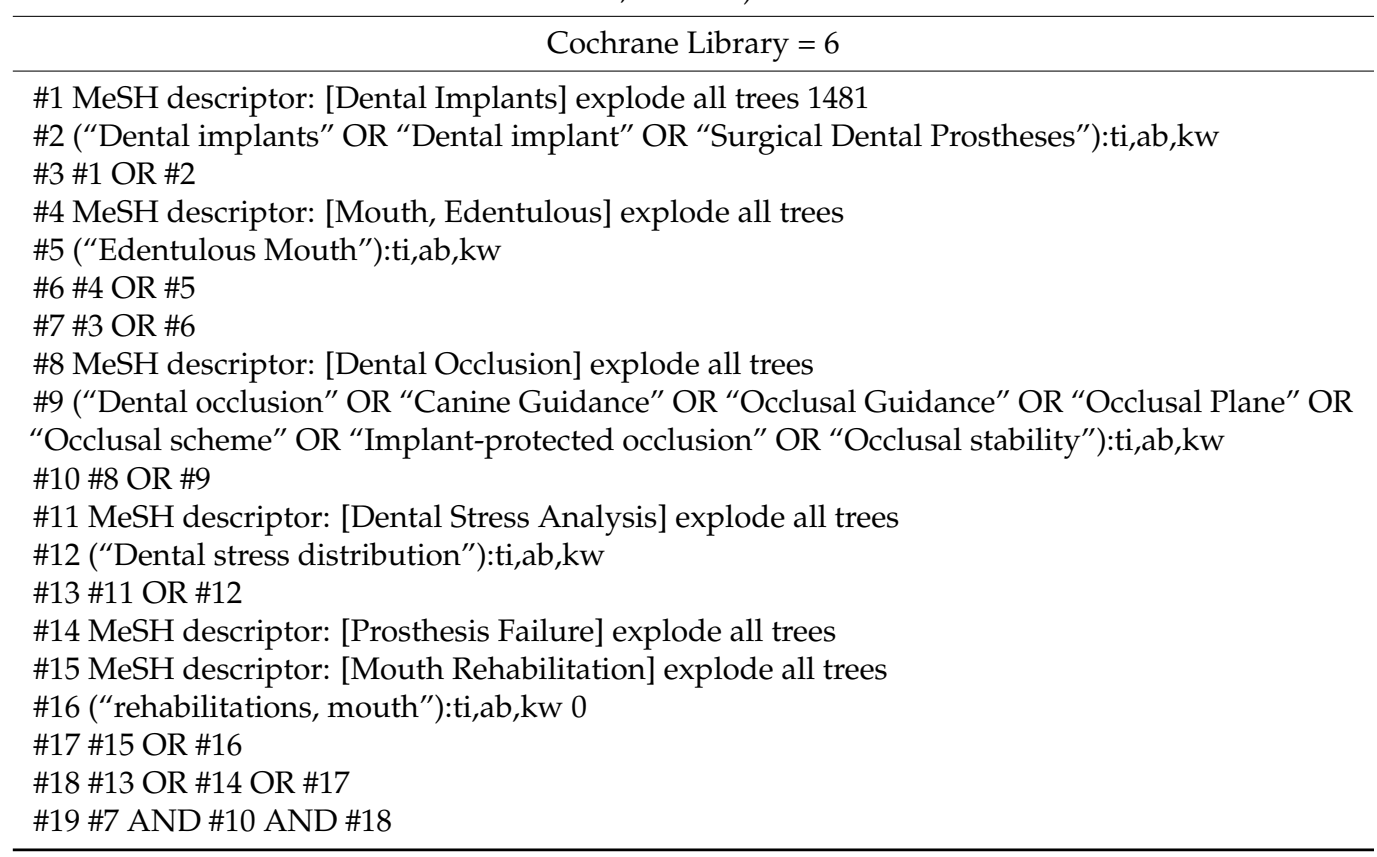


Table 1. Cont.

\begin{tabular}{|c|}
\hline Lilacs $=0$ \\
\hline 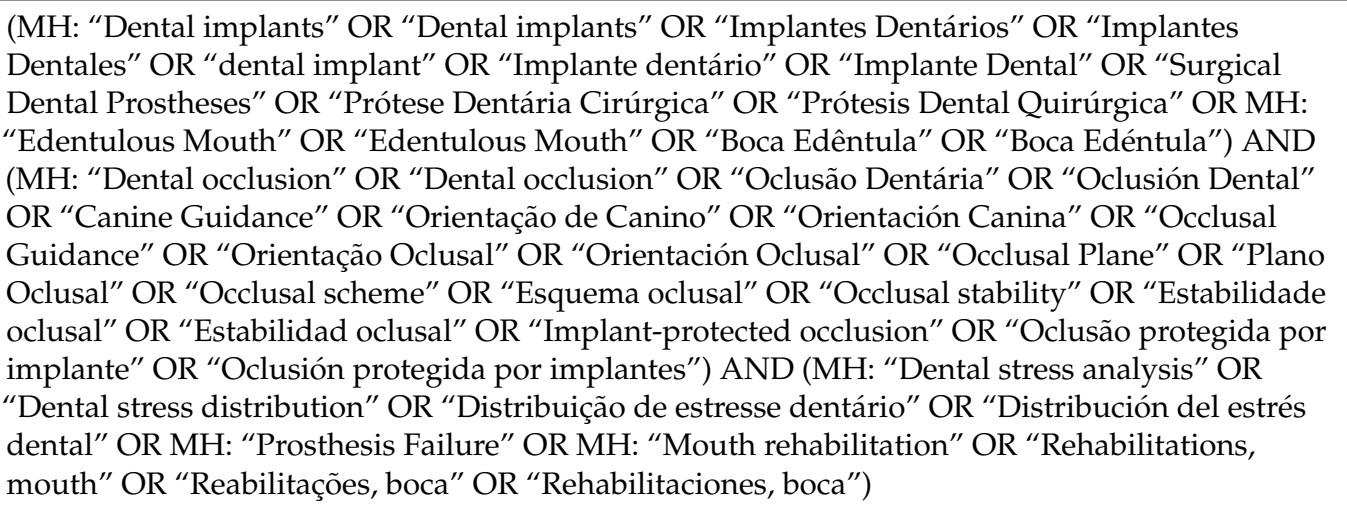 \\
\hline Open Grey $=0$ \\
\hline
\end{tabular}

${ }^{*}$ Article numbers found in each database.

All articles were analyzed by two independent reviewers (GLCL, PFZ), based on the pre-established criteria by this review (following the PICO question). The reviewers loaded the articles in Mendeley reference editor (version 1.19.8, Mendeley Ltd., Amsterdam, The Netherlands) removing the duplicates. The titles and abstracts were selected for inclusion, and after that, full-text reading assessed eligibility. In case of disagreement between the reviewers, discussions were held to establish an inclusion or exclusion agreement for the study in question. In this systematic review the K Cohen test has been performed for the accuracy and reliability. Both operators that selected the articles followed the review protocols and guidelines. The $\%$ of agreement between the authors was calculated in $97.2 \%$ with a Cohen's K coefficient equal 0.43.

The in vitro and finite element analysis studies were included because they complemented the occlusion analysis in different methodologies, enabling a better understanding of the biomechanical response, correlating with the clinical studies included in this systematic review.

\subsection{Quality Assessment of Risk of Bias}

The risk of bias of the included studies was assessed using the Cochrane collaboration' tool. The assessment was analyzed according to seven established criteria that the article must have in their studies (according to each article type) and classified in tree levels: The high risk was considered when only two criteria were included, the middle risk until 3 and 4 criteria were included, and low risk when 5,6 or 7 criteria were included.

\section{Results}

The electronic search identified 632 publications, and after removing the duplicates, 521 studies remained. Applying the inclusion criteria, 32 papers were selected with potentially relevant, and six of them were selected. However, one article [13] was excluded because it was not possible to access the full text, so five studies [14-18] were used in this systematic review, corresponding to one clinical trial, one retrospective clinical trial, one in vitro and two in silico (finite element analysis-FEA). The meta-analysis evaluation and the "Assessment of Risk of Bias" were not conducted because of the heterogeneity of the included studies. The PRISMA flowchart for this systematic review is depicted in Figure 1. A table of specific characteristics was made for clinical trials studies (Table 2), and a general table for all included studies, divided into part A and part B (Table 3). 


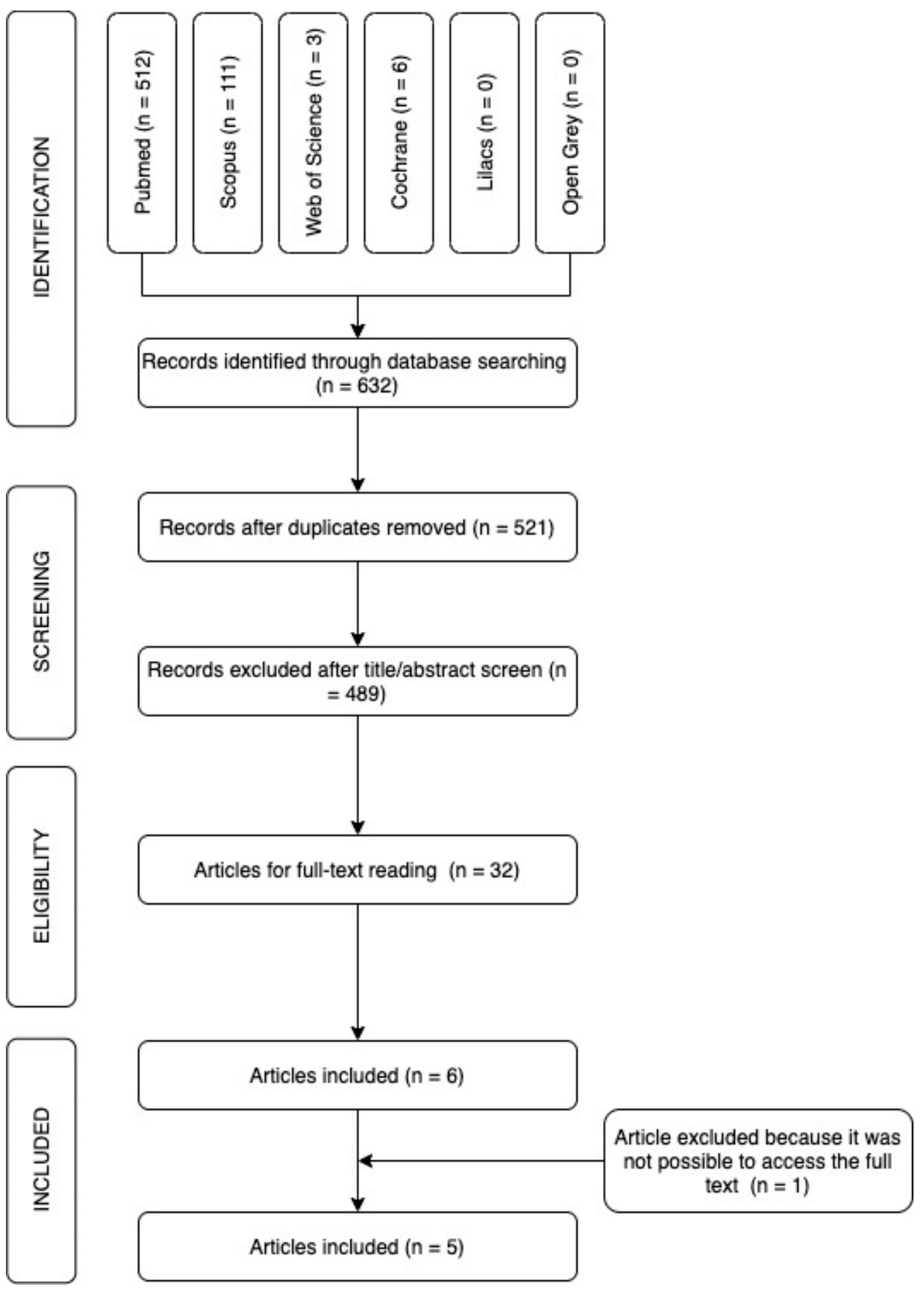

Figure 1. PRISMA flowchart. 
Table 2. Clinical trials studies' specific characteristics ( $n=2$ articles).

\begin{tabular}{|c|c|c|c|c|c|}
\hline $\begin{array}{l}\text { First Author (Year) } \\
\text { [Reference] }\end{array}$ & $n$ & Patients Characteristics & $\begin{array}{l}\text { Observation } \\
\text { Time }\end{array}$ & Type of Analysis & Ethical Comitêe \\
\hline $\begin{array}{l}\text { Linkevicius et al. } \\
\text { (2008) [15] }\end{array}$ & 251-(21) & $\begin{array}{l}\text { Male and Female with the } \\
\text { average age of } \\
42.1 \pm 11.3 \text { years (range } \\
\text { from } 19 \text { to } 76 \text { years old) }\end{array}$ & $1-48$ months & $\begin{array}{l}\text { Clinical inspection- } \\
\text { Ceramic failure }\end{array}$ & $\begin{array}{l}\text { All the patients included } \\
\text { into the study gave } \\
\text { informed content to use }\end{array}$ \\
\hline Falk et al. (1990) [14] & 8 & $\begin{array}{l}\text { Six men and two women } \\
\text { participated in this study. } \\
\text { Their mean age was } \\
56 \text { years (range } 43 \text { to } 65 \text { ) }\end{array}$ & $\begin{array}{l}\text { Immediately } \\
\text { evaluation }\end{array}$ & $\begin{array}{l}\text { Force recording. Mingograf } \\
\text { jet recorder (Elema } \\
\text { Schönander, Solna, Sweden) } \\
\text { via a 9-V battery-powered } \\
\text { bridge amplifier. The } \\
\text { occlusal forces were then } \\
\text { measured according to a } \\
\text { standardized } \\
\text { test program. }\end{array}$ & $\begin{array}{l}\text { Ethical disclosure not } \\
\text { mentioned. } \\
\text { Patients from } \\
\text { Department of } \\
\text { Prosthodontics at The } \\
\text { Institute for Postgraduate } \\
\text { Dental Education, } \\
\text { Jönköping, Sweden. }\end{array}$ \\
\hline
\end{tabular}

Table 3. General characteristics of included studies ( $n=5$ articles).

\begin{tabular}{|c|c|c|c|c|c|c|c|}
\hline \multicolumn{8}{|c|}{ Part A } \\
\hline $\begin{array}{l}\text { First Author } \\
\text { (Year) } \\
\text { [Reference] }\end{array}$ & Country & $\begin{array}{l}\text { Study } \\
\text { Type }\end{array}$ & Purpose of Study & Analyzed Groups & $\begin{array}{l}\text { Analyzed } \\
\text { Occlusion }\end{array}$ & Test Type & Results \\
\hline $\begin{array}{l}\text { Greco et al. } \\
(2010) \text { [17] }\end{array}$ & Brazil & FEA & $\begin{array}{l}\text { Compared the } \\
\text { stresses generated by } \\
\text { the disocclusion in } \\
\text { the canine guide } \\
\text { occlusion (CGO) and } \\
\text { bilateral balanced } \\
\text { occlusion (BBO) on } \\
\text { the implants and } \\
\text { metallic } \\
\text { infrastructure of a } \\
\text { modified Brånemark } \\
\text { protocol }\end{array}$ & $\begin{array}{l}\text { (1) Nodal load of } \\
15 \mathrm{~N} \text { with an angle } \\
\text { of } 45^{\circ} \text { to the canine } \\
\text { tooth-CGO } \\
\text { (2) Nodal load of } \\
15 \mathrm{~N} \text { with a angle } \\
\text { of } 45^{\circ} \text { distributed } \\
\text { across three } \\
\text { teeth-BBO }\end{array}$ & Not mentioned & $\begin{array}{l}\text { Linear elastic } \\
\text { static analysis } \\
\text { (maximum } \\
\text { stress) }\end{array}$ & $\begin{array}{l}\text { The disocclusion in } \\
\text { BBO induced lower } \\
\text { tensions than those in } \\
\text { CGO in a mandibular } \\
\text { complete denture } \\
\text { supported by } \\
\text { implants without free } \\
\text { distal ends }\end{array}$ \\
\hline $\begin{array}{l}\text { Türker et al. } \\
\text { (2019) [13] }\end{array}$ & $\begin{array}{c}\text { Turkey } \\
\text { and } \\
\text { USA }\end{array}$ & FEA & $\begin{array}{l}\text { Evaluate stress } \\
\text { distributions on } \\
\text { implants and alveolar } \\
\text { bone due to occlusal } \\
\text { load produced } \\
\text { during chewing by } \\
\text { prostheses prepared } \\
\text { according to the } \\
\text { All-on-Four concept } \\
\text { with different } \\
\text { occlusal schemes }\end{array}$ & $\begin{array}{l}\text { (1) CGO: occlusal } \\
\text { scheme prepared } \\
\text { according to } \\
\text { canine-guided } \\
\text { occlusion } \\
\text { (2) GFO: occlusal } \\
\text { scheme prepared } \\
\text { according to group } \\
\text { function occlusion } \\
\text { (3) BBO: occlusal } \\
\text { scheme prepared } \\
\text { according to } \\
\text { bilateral balanced } \\
\text { occlusion } \\
\text { (4) LO: occlusal } \\
\text { scheme prepared } \\
\text { according to } \\
\text { lingualized } \\
\text { occlusion } \\
\text { (5) MO: occlusal } \\
\text { scheme prepared } \\
\text { according to } \\
\text { monoplane } \\
\text { occlusion }\end{array}$ & $\begin{array}{l}\text { Maximum } \\
\text { intercuspation } \\
(450 \mathrm{~N}) \\
\text { Lateral } \\
\text { movement } \\
\text { (93 N to CGO; } \\
200 \mathrm{~N} \text { to GFO; } \\
400 \mathrm{~N} \text { to BBO, } \\
\mathrm{LO} \text { and MO) } \\
\text { Protrusive } \\
\text { movement } \\
\text { (94 N to CGO } \\
\text { and CFO; } 400 \\
\mathrm{~N} \text { to BBO, LO } \\
\text { and MO) }\end{array}$ & $\begin{array}{l}\text { Stress outputs } \\
\text { for the maxilla } \\
\text { and mandible } \\
\text { were taken as } \\
\text { maximum } \\
\text { principal stress } \\
\text { (Pmax) and } \\
\text { minimum } \\
\text { principal stress } \\
\text { (Pmin). Von } \\
\text { Mises stress } \\
\text { values were } \\
\text { obtained for } \\
\text { the implants }\end{array}$ & $\begin{array}{l}\text { The highest stress } \\
\text { values on alveolar } \\
\text { bone occurred } \\
\text { around the neck } \\
\text { region of the } \\
\text { implants in cortical } \\
\text { bone, and the highest } \\
\text { stress values on } \\
\text { implants occurred at } \\
\text { the neck region of the } \\
\text { implants } \\
\text { The highest stress } \\
\text { values were observed } \\
\text { in maximum } \\
\text { intercuspation with } \\
\text { monoplane occlusion, } \\
\text { during protrusive } \\
\text { movement with BBO, } \\
\text { and during lateral } \\
\text { movement with } \\
\text { bilateral balanced } \\
\text { and monoplane } \\
\text { occlusion } \\
\text { The lowest stress } \\
\text { values were observed } \\
\text { with canine- guided } \\
\text { occlusion in all } \\
\text { conditions and on } \\
\text { all structures }\end{array}$ \\
\hline
\end{tabular}


Table 3. Cont.

\begin{tabular}{|c|c|c|c|c|c|c|c|}
\hline \multicolumn{8}{|c|}{ Part A } \\
\hline $\begin{array}{l}\text { First Author } \\
\text { (Year) } \\
\text { [Reference] }\end{array}$ & Country & $\begin{array}{l}\text { Study } \\
\text { Type }\end{array}$ & Purpose of Study & Analyzed Groups & $\begin{array}{l}\text { Analyzed } \\
\text { Occlusion }\end{array}$ & Test Type & Results \\
\hline $\begin{array}{l}\text { Block et al. } \\
\text { (2017) [16] }\end{array}$ & Israel & In vitro & $\begin{array}{l}\text { Investigate the effect } \\
\text { of implant insertion } \\
\text { on the strain levels in } \\
\text { bovine bone and to } \\
\text { evaluate the effect of } \\
\text { simulated } \\
\text { mastication cycles on } \\
\text { the strain levels } \\
\text { around implants, in } \\
\text { splinted and } \\
\text { nonsplinted } \\
\text { restorations with } \\
\text { different } \\
\text { occlusal schemes. }\end{array}$ & $\begin{array}{l}\text { Full splint (FS) } \\
\text { loading: complete } \\
\text { cross-arch splint } \\
\text { force on entire } \\
\text { metal plate. } \\
\text { Segmented } \\
\text { cross-arch splint } \\
\text { (SS) loading: metal } \\
\text { plate cut in the } \\
\text { midline and force } \\
\text { applied on the } \\
\text { entire metal plate. } \\
\text { 3. Canine loading } \\
\text { (CL): disconnecting } \\
\text { right canine from } \\
\text { distal teeth while } \\
\text { maintaining } \\
\text { proximal contact } \\
\text { with adjacent } \\
\text { premolar. Metal } \\
\text { plate also cut } \\
\text { accordingly. Load } \\
\text { applied on tooth } 6 . \\
\text { Premolar } \\
\text { loading:Premolar } \\
\text { loading (PL): } \\
\text { splinted group } \\
\text { function } \\
\text { restoration in same } \\
\text { configuration as in } \\
\text { CL (teeth } 4 \text { and } 3 \\
\text { connected). Load } \\
\text { applied on teeth } 5 \\
\text { and } 4 . P r e m o l a r- \\
\text { segmented loading } \\
\text { (PSL): nonsplinted } \\
\text { group function } \\
\text { disconnecting } \\
\text { second premolar } \\
\text { from first molar } \\
\text { while maintaining } \\
\text { proximal contacts } \\
\text { with adjacent teeth. } \\
\text { Metal plate also cut } \\
\text { accordingly. Load } \\
\text { applied on teeth } 5 \\
\text { and } 4 . \\
\text { Single implant } \\
\text { loading (SL): } \\
\text { loading of first } \\
\text { molars full } \\
\text { separation of tooth } \\
3 \text { from adjacent } \\
\text { teeth. Load applied } \\
\text { only on tooth } 3 .\end{array}$ & $\begin{array}{l}\text { Canine } \\
\text { guidance, and } \\
\text { group function } \\
\text { configurations. }\end{array}$ & $\begin{array}{l}\text { The restoration } \\
\text { was loaded by } \\
\text { an Instron } \\
\text { machine } \\
\text { (model 4502; } \\
\text { Instron Corp., } \\
\text { Bucking- } \\
\text { hamshire, } \\
\text { United } \\
\text { Kingdom) with } \\
\text { a force } \\
\text { amplitude of } \\
135 \mathrm{~N} \text { at a } \\
\text { sinus of } 1 \mathrm{~Hz} \\
\text { for } 300 \text { cycles, } \\
\text { simulating } \\
5 \text { min of } \\
\text { mastication. } \\
\text { Strain was } \\
\text { measured } \\
\text { during loading, } \\
\text { and residual } \\
\text { strain } \\
\text { measurements } \\
\text { were recorded } \\
\text { after loading } \\
\text { stopped }\end{array}$ & $\begin{array}{l}\text { Comparing the } \\
3 \text { different guidance } \\
\text { configurations, PL } \\
\text { presented the most } \\
\text { favorable strain } \\
\text { results both in } \\
\text { loading, showing the } \\
\text { best distribution of } \\
\text { vertical compared } \\
\text { with horizontal } \\
\text { strain, and in } \\
\text { residual strain with } \\
\text { the lowest horizontal } \\
\text { strain values } \\
\text { ( } p<0.05) \text {. The least } \\
\text { favorable strain } \\
\text { results were in CL } \\
\text { where there were the } \\
\text { highest levels of } \\
\text { horizontal strain in } \\
\text { loading and even } \\
\text { higher levels of } \\
\text { horizontal residual } \\
\text { strain }(p<0.05) \\
\text { Premolar loading } \\
\text { guidance presented } \\
\text { the most favorable } \\
\text { loading and residual } \\
\text { strain results } \\
(p<0.05)\end{array}$ \\
\hline
\end{tabular}


Table 3. Cont.

\begin{tabular}{|c|c|c|c|c|c|c|c|}
\hline \multicolumn{8}{|c|}{ Part A } \\
\hline $\begin{array}{l}\text { First Author } \\
\text { (Year) } \\
\text { [Reference] }\end{array}$ & Country & $\begin{array}{l}\text { Study } \\
\text { Type }\end{array}$ & Purpose of Study & Analyzed Groups & $\begin{array}{l}\text { Analyzed } \\
\text { Occlusion }\end{array}$ & Test Type & Results \\
\hline $\begin{array}{c}\text { Linkevicius } \\
\text { et al. (2008) } \\
{[15]}\end{array}$ & Lithuania & $\begin{array}{c}\text { Clinical } \\
\text { Trials }\end{array}$ & $\begin{array}{l}\text { Define the fracture } \\
\text { rate of implant } \\
\text { supported } \\
\text { metal-ceramic } \\
\text { restorations } \\
\text { delivered in private } \\
\text { practice, and to } \\
\text { identify if a } \\
\text { restoration's contact } \\
\text { during eccentric } \\
\text { mandible movements } \\
\text { has any influence on } \\
\text { ceramic fracture rates }\end{array}$ & $\begin{array}{l}\text { A regular occlusal } \\
\text { scheme } \\
\text { was applied. } \\
\text { Habitual occlusal } \\
\text { position,occlusal } \\
\text { contacts were } \\
\text { not positioned on } \\
\text { oblique planes and } \\
\text { posterior } \\
\text { prostheses did not } \\
\text { have contact } \\
\text { during eccentric } \\
\text { mandible } \\
\text { movements } \\
3 \text { types of } \\
\text { rehabilitations: } \\
\text { - single crowns } \\
\text { - fixed partial } \\
\text { dentures } \\
\text { - full cross-arch } \\
\text { reconstructions } \\
4 \text { follow up time } \\
\text { groups: } \\
\text { - 1 year } \\
\text { - 1-2 years } \\
\text { - 2-3 years } \\
\text { - Over } 3 \text { years }\end{array}$ & $\begin{array}{l}\text { Eccentric } \\
\text { mandibular } \\
\text { movements }\end{array}$ & $\begin{array}{l}\text { Clinical } \\
\text { Inspected for } \\
\text { the presence of } \\
\text { mechanical } \\
\text { complications, } \\
\text { namely } \\
\text { ceramic } \\
\text { fractures. They } \\
\text { were } \\
\text { distinguished } \\
\text { as: } \\
\text { adhesive } \\
\text { co-adhesive }\end{array}$ & $\begin{array}{l}\text { Full-arch } \\
\text { metal-ceramic } \\
\text { restorations } \\
\text { experienced } 38.1 \% \\
\text { chipping.The } \\
\text { majority of the } \\
\text { failures in the current } \\
\text { study were of } \\
\text { co-adhesive kind } \\
\text { The difference } \\
\text { between the full-arch } \\
\text { restorations and } \\
\text { single or partial fixed } \\
\text { crown groups was } \\
\text { found to be } \\
\text { statistically } \\
\text { significant. } \\
\text { It was concluded that } \\
54.2 \% \text { of all failures } \\
\text { occurred in guiding } \\
\text { restorations } \\
\text { Consequently, } \\
\text { contact during } \\
\text { eccentric mandibular } \\
\text { movements } \\
\text { significantly } \\
\text { increases the } \\
\text { possibility of } \\
\text { veneer complication }\end{array}$ \\
\hline $\begin{array}{l}\text { Falk et al. } \\
\text { (1990) [14] }\end{array}$ & Sweden & $\begin{array}{l}\text { Clinical } \\
\text { Trials }\end{array}$ & $\begin{array}{l}\text { The aim of this study } \\
\text { was to determine } \\
\text { whether a small, } \\
\text { experimentally } \\
\text { introduced, } \\
\text { premature occlusal } \\
\text { contact on the distal } \\
\text { cantilever unit in } \\
\text { dentitions with } \\
\text { fixture-supported } \\
\text { prostheses occluding } \\
\text { with complete } \\
\text { dentures would } \\
\text { further amplify the } \\
\text { unfavorable } \\
\text { distribution of axially } \\
\text { directed } \\
\text { occlusal forces }\end{array}$ & $\begin{array}{l}\text { Basic occlusion } \\
\text { with simultaneous } \\
\text { occlusal contacts in } \\
\text { habitual occlusion } \\
\text { interfered } \\
\text { occlusion in } \\
\text { habitual occlusion } \\
\text { Basic occlusion in } \\
\text { preferred chewing } \\
\text { side.Interfered } \\
\text { occlusion with a } \\
\text { 100- } \mu \text { m-high } \\
\text { premature occlusal } \\
\text { contact on the } \\
\text { second cantilever } \\
\text { unit of the } \\
\text { preferred } \\
\text { chewing side. }\end{array}$ & $\begin{array}{l}\text { Closing forces } \\
\text { in habitual } \\
\text { occlusion and } \\
\text { chewing } \\
\text { movements } \\
\text { and preferred } \\
\text { and non- } \\
\text { preferred side. }\end{array}$ & $\begin{array}{l}\text { Local and total } \\
\text { maximal } \\
\text { closing forces } \\
\text { in habitual } \\
\text { occlusion } \\
\text { Mean local and } \\
\text { total chewing } \\
\text { forces } \\
\text { calculated } \\
\text { from one } \\
\text { randomly } \\
\text { selected } \\
\text { chewing } \\
\text { sequence.For } \\
\text { force recording, } \\
\text { the transducers } \\
\text { were } \\
\text { connected to a } \\
\text { Mingograf jet } \\
\text { recorder } \\
\text { (Elema } \\
\text { Schönander, } \\
\text { Solna, Sweden) } \\
\text { via a 9-V } \\
\text { battery- } \\
\text { powered } \\
\text { bridge } \\
\text { amplifier. The } \\
\text { occlusal forces } \\
\text { were then } \\
\text { measured } \\
\text { according to a } \\
\text { standardized } \\
\text { test program. }\end{array}$ & $\begin{array}{l}\text { The premature } \\
\text { occlusal contact of } \\
\text { the preferred } \\
\text { chewing side had no } \\
\text { influence on the total } \\
\text { maximal closing } \\
\text { forces as compared to } \\
\text { basic occlusion. The } \\
\text { group mean local } \\
\text { closing force at the } \\
\text { interfered was } \\
\text { significantly } \\
\text { increased ( } p<0.05) \text {. } \\
\text { The interfered } \\
\text { occlusion resulted in } \\
\text { a slight, although } \\
\text { nonsignificant, } \\
\text { increase of the } \\
\text { vertical bending } \\
\text { stress during closing } \\
\text { but had no effect on } \\
\text { the chewing vertical } \\
\text { bending stress }\end{array}$ \\
\hline
\end{tabular}


Table 3. Cont.

\begin{tabular}{|c|c|c|c|c|c|}
\hline \multicolumn{6}{|c|}{ Part B } \\
\hline $\begin{array}{c}\text { First Author } \\
\text { (Year) } \\
\text { [Reference] }\end{array}$ & $\begin{array}{l}\text { Region } \\
\text { of Study }\end{array}$ & Number of Implants & $\begin{array}{l}\text { Feature of the } \\
\text { Implants }\end{array}$ & Materials Type & Antagonist Type \\
\hline $\begin{array}{l}\text { Greco et al. } \\
(2010) \text { [17] }\end{array}$ & $\begin{array}{l}\text { A model } \\
\text { simulat- } \\
\text { ing a } \\
\text { jaw }\end{array}$ & $\begin{array}{l}5 \text { installed between the mental } \\
\text { foramen, with a distance of } 4 \mathrm{~mm} \\
\text { between their platforms and } 2 \\
\text { located at the midpoint of the } \\
\text { occlusal surface of the first molar }\end{array}$ & $\begin{array}{l}\text { All implants were } \\
\text { cylindrical. The } \\
\text { dimension of } \\
13 \mathrm{~mm} \text { in height } \\
\text { and } 3.75 \mathrm{~mm} \text { in } \\
\text { diameter is about } \\
\text { the } 5 \text { implants in } \\
\text { anterior area; } 5 \mathrm{~mm} \\
\text { in height and } 5 \mathrm{~mm} \\
\text { in diameter is } \\
\text { about the } 2 \\
\text { implantes in } \\
\text { posterior area }\end{array}$ & $\begin{array}{l}\text { Implants anterior area: } \\
\text { (Brånemark System }{ }^{\circledR} \\
\text { Mk } \\
\text { III Groovy; Nobel }{ }^{\circledR} \text { Biocare, } \\
\text { Zürich-Flughafen, } \\
\text { Switzerland); Posterior area: } \\
\text { (Titamax WS }{ }^{\circledR} \text {; Neodent }{ }^{\circledR} \text {, } \\
\text { Curitiba, PR, Brazil) } \\
\text { Prosthetic components made of } \\
\text { titanium were } 3 \text { mm in height } \\
\text { (Multi-unit Abutment }{ }^{\circledR} \text {; Nobel } \\
\text { Biocare }{ }^{\circledR} \text { ) } \\
\text { A nickel-chromium infrastructure } \\
\text { (Wiron }{ }^{\circledR} \\
\text { BEGO, Goldschlangerar, Bremen, } \\
\text { Germany) with a thickness of } \\
6 \text { mm, a height of } 4 \text { mm and a } \\
\text { total length of } 112 \text { mm with free } \\
\text { distal ends } \\
12 \text { dental elements in acrylic resin } \\
\text { with a range of } 2 \text { mm of gingival }\end{array}$ & Not applicable \\
\hline
\end{tabular}

Implants: OsseoSpeed tx $4.0 \mathrm{~S}$

Astra Tech; Dentsply Sirona,

York, PA

4 implants in maxilla: distance from the midline to the anterior implant in the was $15.4 \mathrm{~mm}$, the distance between the two implants was $30.8 \mathrm{~mm}$, and the distance between the anterior and

Türker et al Human (2019) [13] maxilla and jaw
The implants were internal hexagon

type.

Distal sloping of posterior region implants was performed at $40^{\circ}$ for both the maxilla and mandible Dimension of $4 \times 10 \mathrm{~mm}^{2}$ for the anterior region and $4 \times 13 \mathrm{~mm}^{2}$ for the posterior region
Bovine

jaw and 8 Implants, teeth location

Block et al maxil-

(2017) [16] numbers: $2,3,4,6$, and $11,13,14$

lary 15 (position of canines, second

teeth premolars, first and was set second molars).

up
Not mentioned

Flat abutment for the anterior region $\left(20^{\circ}\right.$ UniAbutment 3.5/4.0

Astra Tech), and angulated abutment (Angled Abutment 3.5/4.0; Astra Tech)

The bar structure in the maxilla was $5 \mathrm{~mm}$ wide, $3 \mathrm{~mm}$ high, and $95.8 \mathrm{~mm}$ long. The bar structure in the mandible was $94.8 \mathrm{~mm}$ long, and despite variation in different regions, it was $5 \mathrm{~mm}$ wide and $3 \mathrm{~mm}$ long on average (not mentioned the material) Teeth with sim- ilar crown sizes and crown widths were chosen for all occlusal concepts (Ivostar; Ivoclar Vivadent)

Titanium-alloy abutments were connected to the implant analogs.(SPI;Alpha-BioTec, Petah-Tiqwa, Israel). A full-arch cast metal restoration were placed on the abutments. This restoration consisted of a metal framework with 5 dental units on each side of the arch.

Titanium implants (BioHorizons, Ala, USA)

Metal- ceramic. frameworks alloy Co-Cr was used as base metal. Different ceramics were used for

Linkevicius et al. (2008) [15]
Maxillary Not mentioned and jaw
Not mentioned layering in fabrication of prostheses

GC Initial (GC, Japan), Inspiration (Heimerle-Meule, Germany)

Design (Ivoclar, Liechtenstein)

Vita VM7 (Vita Zahnfabrik,

Germany)
Not applicable

All-on-Four protocols

Full arch rehabilitation 
Table 3. Cont.

\begin{tabular}{|c|c|c|c|c|c|}
\hline \multicolumn{6}{|c|}{ Part B } \\
\hline $\begin{array}{l}\text { First Author } \\
\text { (Year) } \\
\text { [Reference] }\end{array}$ & $\begin{array}{l}\text { Region } \\
\text { of Study }\end{array}$ & Number of Implants & $\begin{array}{l}\text { Feature of the } \\
\text { Implants }\end{array}$ & Materials Type & Antagonist Type \\
\hline $\begin{array}{l}\text { Falk et al. } \\
\text { (1990) [14] }\end{array}$ & $\begin{array}{l}\text { Anterior } \\
\text { region of } \\
\text { the jaw, } \\
\text { between } \\
\text { the } \\
\text { mental } \\
\text { foram- } \\
\text { ina }\end{array}$ & 5 or 6 titanium implants & $\begin{array}{l}\text { The shape of the } \\
\text { cantilever joints } \\
\text { was roughly } \\
\text { elliptic, and the } \\
\text { dimensions of the } \\
\text { joints as well as the } \\
\text { whole metal } \\
\text { framework of the } \\
\text { construction were } \\
\text { approximately } 5 \\
\text { mm high and } 4 \\
\text { mm wide. The } \\
\text { yield strength for } \\
\text { hardened type III } \\
\text { gold alloy is } \\
\text { approximately } 440 \\
\mathrm{~N} / \mathrm{mm}^{2} \text {, and for } \\
\text { unhardened it is } \\
\text { approximately } \\
310 \mathrm{~N} / \mathrm{mm}^{2}\end{array}$ & $\begin{array}{l}\text { Titanium fixtures. The metal } \\
\text { frameworks were cast in type III } \\
\text { dental gold alloy }\end{array}$ & Complete dentures \\
\hline
\end{tabular}

\section{Quality Assessment of Risk of Bias}

A high level of bias was evident in one publication included in this review, a low level of bias was evident in two publications included in this review and two publications were considered to have a medium risk of bias. Table 4 shows the quality assessment of the studies and the risk of bias.

Table 4. Quality assessment of the included studies. Red is high level of bias, yellow is middle risk of bias, green is low risk of bias and blue is unclear data. Not applicable scores (N/A) was also used due to the heterogeneity of data.

\begin{tabular}{|c|c|c|c|c|c|c|c|c|}
\hline & $\begin{array}{c}\text { Sample } \\
\text { Calculation } \\
\text { or } \\
\text { Numerical } \\
\text { Model } \\
\text { Validation }\end{array}$ & $\begin{array}{l}\text { Sample Ran- } \\
\text { domization }\end{array}$ & $\begin{array}{c}\text { The } \\
\text { Number (n) } \\
\text { of } \\
\text { Specimens/ } \\
\text { Patients Is } \\
\text { Clear }\end{array}$ & $\begin{array}{l}\text { Parameters for } \\
\text { Clinical } \\
\text { Analysis } \\
\text { Standardized } \\
\text { or Boundary } \\
\text { Conditions } \\
\text { with Proper } \\
\text { References }\end{array}$ & $\begin{array}{l}\text { Ethical } \\
\text { Committee }\end{array}$ & $\begin{array}{l}\text { Blind } \\
\text { Analysis }\end{array}$ & $\begin{array}{l}\text { Parameters } \\
\text { for the } \\
\text { Mechanical } \\
\text { Test }\end{array}$ & $\begin{array}{l}\text { Overall Risk } \\
\text { of Bias }\end{array}$ \\
\hline \multicolumn{9}{|l|}{$\begin{array}{c}\text { Linkevicius } \\
\text { et al. (2008) } \\
\text { [15] }\end{array}$} \\
\hline $\begin{array}{l}\text { Falk et al. } \\
\text { (1990) [14] }\end{array}$ & & & & & & & $\mathrm{N} / \mathrm{A}$ & \\
\hline $\begin{array}{l}\text { Block et al. } \\
\text { (2017) [16] }\end{array}$ & & N/A & & & N/A & $\mathrm{N} / \mathrm{A}$ & & \\
\hline $\begin{array}{l}\text { Greco et al. } \\
\text { (2010) [17] }\end{array}$ & & N/A & & & N/A & $\mathrm{N} / \mathrm{A}$ & & \\
\hline $\begin{array}{l}\text { Türker et al. } \\
\text { (2019) [13] }\end{array}$ & & N/A & & & N/A & N/A & & \\
\hline
\end{tabular}




\section{Discussion}

The aim of this systematic review was to identify which would be the best occlusal scheme to be used in a complete arch rehabilitation of implant-supported prosthesis. In this search, it was possible to perceive the lack of studies aimed at answering the question proposed in this review. This is a common doubt among prosthetists when it is said about occlusion in implant-supported prostheses, since there is a complexity in planning to get a better distribution of masticatory load between the structures involved [11].

One of the most important criteria for implant success is occlusion, and the implantsupported dentures combine concepts of conventional total dentures and fixed implantsupported dentures $[17,19]$. Implant protected occlusion is an occlusal plan which was designed to provide an improved longevity of both implant and the prosthesis, it was described for the first time by Misch and Bidez [20]. That provides the maximum intercuspation during clenching force and reduces occlusal load on implant, which helps in protecting the implant. For a stable occlusion it is important to avoid overloading the dental implants and the bone, that can lead to biological and mechanical complications. Consequences of biomechanical overloads are early implant failure, early crestal bone lost, intermediate to late implant failure screw loosening, uncemented restoration, component failure, porcelain fracture, prosthesis fracture and peri-implant disease [21,22]. Misch and Bidez identified the factors that can affect the implant protected occlusion, which are as follows: no premature occlusal contacts or interferences (timing of occlusal contacts), influence of surface area, mutually protected articulation, implant body angle to occlusal load, cusp angle of crown (cuspal inclination), cantilever or offset distance, occlusal contact position, implant crown contour, protection of the weakest components, occlusal materials [20]. The influence of crown height is still controversial in literature [20,23].

In addition, a randomized controlled trial demonstrates that implant-supported fixed dental prostheses may require a higher prosthetic maintenance for replacing worn-out components, which in the long term might make this treatment option more expensive than it appears [24]. For that reason, the occlusion planning and further adjustments are necessary to improve the treatment longevity [24].

Regarding the occlusal scheme, the studies are still trying to develop the ideal occlusion pattern for dental implant rehabilitation. According to the articles included in this review, Block et al. concluded that premolar loading guidance presented the most favorable loading and residual strain results, and the least favorable strain results were in canine loading where there were the highest levels of horizontal strain in loading and even higher levels of horizontal residual strain [16]. The authors explained that the possible reason for that finds is the fact that in canine guidance the loaded canine was in contact only distally, referring forces in one direction in a way that the strain grew distally compared with premolar-segmented loading configuration where the loaded premolars were in contact mesially and distally, referring forces in two directions. This was corroborated by the study of Wie [25] which evaluated 56 patients with different occlusal schemes for dental implants and concluded that group function occlusion was the preferred contact pattern, followed by canine guidance and balanced articulation.

Among the in silico studies, Greco et al. [17] compared canine guide occlusion (CGO) with bilateral balanced occlusion (BBO) patterns on a modified Branemark-type total protocol model (without bilateral free extremity). CGO is normally the occlusal pattern expected in natural dentition, so it is also applied in cases of fixed dentures or during orthodontic treatment [26]. In cases of removable complete dentures, BBO is applied to get a better stability of the denture since the distribution of the applied force will be better distributed between the teeth [17]. The stress distribution analyzes showed a higher stress concentration in the CGO than in the BBO. The authors explain that the fact that this happened is because the BBO has three points of contact, and the CGO has only one completely focused on the canine on the working side. This finding corroborates the results of the in vitro study included in this review. The authors also suggest that the use of the "all-on-four", a simplified system where the prosthesis is placed on 
four implant abutments, would perhaps cancel out the tensions generated in the intermediate implants as used in this study, and would achieve an anchorage with better biological and economic advantages. Another finding is that wider implants absorb stress more than longer implants, as the most important area to look at is around the neck of the implant, where bone loss can occur.

In another in silico study, Turker et al. [18] evaluated the stress distribution in the alveolar bone and implants in different models of prosthesis using the "all-on-four" protocol. Five different occlusal schemes were tested-CGO, group functional occlusion, BBO, lingualized occlusion and monoplane occlusal scheme-in three types of contact: maximum intercuspation, lateral and protrusive movement. The findings showed that the highest stress values occur around the implants in the cortical bone and in the neck region of the implant, corroborating other already mentioned studies. Furthermore, the results showed that the posterior region had higher stress concentration values. The authors suggest that this may have happened because the posterior implants are located right in the center of the chewing area, and state that when planning cases, the quality of the bone and the choice of implants for this area should be prioritized. Regarding the tested occlusal schemes, the CGO presented the lowest stress values in all analyzed conditions. The authors report that this must have occurred because anterior and posterior disocclusion occurs in these cases, and oblique loads are avoided on all other teeth. They also state that in a natural condition, canine teeth, as they have long and wide roots, tolerate these loads, conduit in a condition of prosthesis over implant, further experimental studies should be carried out to support this statement.

Falk et al. [14] simulated in a clinical trial an interfered occlusion in implant supported prosthesis with a 100- $\mu \mathrm{m}$-high premature occlusal contact on the second cantilever unit of the preferred chewing side and in habitual occlusion. They concluded that the premature occlusal contact of the preferred chewing side had no influence on the total maximal closing forces as compared to basic occlusion and the interfered occlusion resulted in a slight, but nonsignificant, increase of the vertical bending stress. The authors justify that these facts could be explained by a premature simulated contact might have been too small, considering that there was a complete denture in the opposite jaw compensating for the supracontact with deflecting movements. They also suggest that their findings should be interpreted with caution because premature occlusal contacts have been shown to have a negative influence on the chewing pattern and the masticatory muscle activities, with a consequent risk of development of muscular and temporomandibular joint disorders or leading to increase of fatigue and occlusal overload [14].

In another article included in this review, Linkevicius et al. [15] in their retrospective clinical trial, found that restoration contact during eccentric excursions may significantly increase fracture rates. They discussed that it has been suggested that non-axial loads may be harmful to implant-supported prostheses and should be avoided whenever possible. This study finds evidence that contact during eccentric mandibular movements significantly increases the possibility of veneer complications such as chipping or ceramic fracture. These findings were corroborated the study of Chaichanasiri et al. [27] which concluded in a finite element analysis that the influence of premature contacts in dental implants is very high and a premature contact height of an implant-retained crown over $100 \mu \mathrm{m}$ should be avoided as much as possible to ensure the longevity of dental implants.

The results of this systematic review brought to light the lack of clinical and laboratory studies about occlusion in implant-supported prostheses, especially on implant-protected occlusion, a term which was proposed by Misch and Bidez [20] more than two decades ago, highlighting the importance of the proper distribution of occlusal loads in order to increase the survival of the implants, and consequently, their clinical success. Another important factor that was not considered much in the studies included in this review is the antagonist, since the relationship between the maxilla and the mandible will probably influence the choice of the appropriate occlusal scheme, as the equalization of forces is extremely important to achieve success long-term [11]. 
Despite being interesting, the results by the included FEA studies should be interpreted with care. This numerical method is a computer simulation and does not consider the complex biological and physiological adaptation of the bone around dental implant over time as well as its responses to cyclic occlusal loading [28]. This major limitation of FEA in simulating a follow-up period, considering the bone modelling and the remodeling processes demonstrates that more clinical trials are still necessary about the occlusion topic [28]. In addition, the anisotropic behavior of the bone is another limitation that the selected articles do not consider and this certainly affects the biomechanical response.

The results found in this systematic review also have some limitations due to the heterogeneity of the included studies (clinical prospective, clinical retrospective, in vitro, in silico). Therefore, due the lack of scientific evidence, it is not yet possible to define the best occlusal scheme for the rehabilitation of implant-supported prostheses. However it is clear that the proper distribution of loads and the absence of occlusal interferences can increase the longevity of implants. Thus, more studies are needed to better understand the biomechanical response, since there are several variables involved, such as the number of implants [29], dimensions and positions of the implants, type of support bone, material used in making the prosthesis [30,31], and the antagonist.

\section{Conclusions}

Because of the lack of scientific evidence, it is not possible at this time to define the best occlusal scheme to be used in implant-supported complete dentures. However, there is a consensus that a proper planning for each case, with adequate distribution of loads and the absence of occlusal interferences, can increase the longevity of implantsupported rehabilitations.

Author Contributions: Conceptualization, L.C.L.G., F.Z.P., J.P.M.T., N.d.C.R., E.B., R.M.d.A., L.N.J. and M.A.B.; methodology, E.B.; software, E.B.; validation, L.C.L.G., F.Z.P., J.P.M.T., N.d.C.R., R.M.d.A., L.N.J. and M.A.B.; formal analysis, L.C.L.G., F.Z.P., E.B.; investigation, L.C.L.G. and F.Z.P.; resources, L.C.L.G. and F.Z.P.; data curation, L.C.L.G. and F.Z.P.; writing-original draft preparation, L.C.L.G. and F.Z.P.; writing-review and editing, L.C.L.G. and F.Z.P.; visualization, J.P.M.T., N.d.C.R., E.B., R.M.d.A., L.N.J. and M.A.B.; supervision, J.P.M.T., N.d.C.R., E.B., R.M.d.A., L.N.J. and M.A.B.; project administration, L.C.L.G. and F.Z.P. All authors have read and agreed to the published version of the manuscript.

Funding: This research received no external funding.

Institutional Review Board Statement: Not applicable.

Informed Consent Statement: Not applicable.

Data Availability Statement: Not applicable.

Conflicts of Interest: The authors declare no conflict of interest.

\section{References}

1. Adell, R.; Lekholm, U.; Rockler, B.; Brånemark, P.-I. A 15-Year Study of Osseointegrated Implants in the Treatment of the Edentulous Jaw. Int. J. Oral Surg. 1981, 10, 387-416. [CrossRef]

2. Taylor, T.D.; Agar, J.R. Twenty Years of Progress in Implant Prosthodontics. J. Prosthet. Dent. 2002, 88, 89-95. [CrossRef] [PubMed]

3. Esposito, M.; Hirsch, J.; Lekholm, U.; Thomsen, P. Differential Diagnosis and Treatment Strategies for Biologic Complications and Failing Oral Implants: A Review of the Literature. Int. J. Oral Maxillofac. Implant. 1999, 14, 473-490.

4. Vervaeke, S.; Collaert, B.; Cosyn, J.; Deschepper, E.; De Bruyn, H. A Multifactorial Analysis to Identify Predictors of Implant Failure and Peri-Implant Bone Loss. Clin. Implant Dent. Relat. Res. 2015, 17, e298-e307. [CrossRef] [PubMed]

5. Isidor, F. Loss of Osseointegration Caused by Occlusal Load of Oral Implants. A Clinical and Radiographic Study in Monkeys. Clin. Oral Implant. Res. 1996, 7, 143-152. [CrossRef]

6. Adell, R. Tissue Integrated Prostheses in Clinical Dentistry. Int. Dent. J. 1985, 35, 259-265.

7. Schwarz, M.S. Mechanical Complications of Dental Implants. Clin. Oral Implant. Res. 2000, 11, 156-158. [CrossRef]

8. Rangert, B.R.; Sullivan, R.M.; Jemt, T.M. Load Factor Control for Implants in the Posterior Partially Edentulous Segment. Int. J. Oral Maxillofac. Implant. 1997, 12, 360-370.

9. Koyano, K.; Esaki, D. Occlusion on Oral Implants: Current Clinical Guidelines. J. Oral Rehabil. 2015, 42, 153-161. [CrossRef] 
10. Nikolopoulou, F.; Ktena-agapitou, P. Rationale for Choices of Occlusal Schemes for Complete Dentures Supported by Implants. J. Oral Implantol. 2006, XXXII, 200-203. [CrossRef]

11. Wismeijer, D.; van Waas, M.A.J.; Kalk, W. Factors to Consider in Selecting an Occlusal Concept for Patients with Implants in the Edentulous Mandible. J. Prosthet. Dent. 1995, 74, 380-384. [CrossRef]

12. Page, M.J.; McKenzie, J.E.; Bossuyt, P.M.; Boutron, I.; Hoffmann, T.C.; Mulrow, C.D.; Shamseer, L.; Tetzlaff, J.M.; Akl, E.A.; Brennan, S.E.; et al. The PRISMA 2020 Statement: An Updated Guideline for Reporting Systematic Reviews. BMJ 2021, 372, 1-9. [CrossRef]

13. Türker, N.; Alkiş, H.T.; Sadowsky, S.J.; Şebnem Büyükkaplan, U. Effects of Occlusal Scheme on All-on-Four Abutments, Screws, and Prostheses: A Three-Dimensional Finite Element Study. J. Oral Implantol. 2021, 47, 18-24. [CrossRef] [PubMed]

14. Falk, H.; Laurell, L.; Lundgren, D. Occlusal Interferences and Cantilever Joint Stress in Implant-Supported Prostheses Occluding with Complete Dentures. Int. J. Oral Maxillofac. Implant. 1990, 5, 70-77.

15. Linkevicius, T.; Vladimirovas, E.; Grybauskas, S.; Puisys, A.; Rutkunas, V. Veneer Fracture in Implant-Supported Metal-Ceramic Restorations. Part I: Overall Success Rate and Impact of Occlusal Guidance. Stomatol. Balt. Dent. Maxilofac. J. 2008, 10, 133-139.

16. Block, J.; Matalon, S.; Tanase, G.; Ormianer, Z. Effect of Restorative Configurations and Occlusal Schemes on Strain Levels in Bone Surrounding Implants. Implant. Dent. 2017, 26, 1-7. [CrossRef] [PubMed]

17. Greco, G.D.; de Las Casas, E.; Cornacchia, T.P.M.; de Magalhaes, C.S.; Moreira, A.N. Standard of Disocclusion in Complete Dentures Supported by Implants without Free Distal Ends: Analysis by the Finite Elements Method. J. Appl. Oral Sci. 2012, 20, 64-69. [CrossRef] [PubMed]

18. Türker, N.; Büyükkaplan, U.S.; Sadowsky, S.J.; Özarslan, M.M. Finite Element Stress Analysis of Applied Forces to Implants and Supporting Tissues Using the "All-on-Four" Concept with Different Occlusal Schemes. J. Prosthodont. 2019, 28, 185-194. [CrossRef] [PubMed]

19. Swaminathan, Y.; Rao, G. Implant Protected Occlusion. J. Dent. Med. Sci. 2013, 11, 20-25. [CrossRef]

20. Misch, C.E.; Bides, M.W. Implant-Protected Occlusion. Int. J. Dent. Symp. 1994, 2, 32-37.

21. Chen, Y.Y.; Kuan, C.L.; Wang, Y.B. Implant Occlusion: Biomechanical Considerations for Implant-Supported Prostheses. J. Dent. Sci. 2008, 3, 65-74.

22. Kim, Y.; Oh, T.-J.; Misch, C.E.; Wang, H.-L. Occlusal Considerations in Implant Therapy: Clinical Guidelines with Biomechanical Rationale. Clin. Oral Implant. Res. 2005, 16, 26-35. [CrossRef]

23. Felice, P.; Checchi, L.; Barausse, C.; Pistilli, R.; Sammartino, G.; Masi, I.; Ippolito, D.R.; Esposito, M. Posterior jaws rehabilitated with partial prostheses supported by $4.0 \times 4.0 \mathrm{~mm}^{2}$ or by longer implants: One-year post-loading results from a multicenter randomised controlled trial. Eur. J. Oral Implantol. 2016, 9, 35-45.

24. Cannizzaro, G.; Felice, P.; Gherlone, E.; Barausse, C.; Ferri, V.; Leone, M.; Trullenque-Eriksson, A.; Esposito, M. Immediate loading of two (fixed-on-2) vs four (fixed-on-4) implants placed with a flapless technique supporting mandibular cross-arch fixed prostheses: 3-year results from a pilot randomised controlled trial. Eur. J. Oral Implantol. 2017, 10, $133-145$.

25. Wie, H. Registration of Localization, Occlusion and Occluding Materials for Failing Screw Joints in the Brånemark Implant System. Clin. Oral Implant. Res. 1995, 6, 47-53. [CrossRef]

26. Ogawa, T.; Ogimoto, T.; Koyano, K. Pattern of Occlusal Contacts in Lateral Positions: Canine Protection and Group Function Validity in Classifying Guidance Patterns. J. Prosthet. Dent. 1998, 80, 67-74. [CrossRef]

27. Chaichanasiri, E.; Nanakorn, P.; Tharanon, W.; Sloten, J. Vander Finite Element Analysis of Bone around a Dental Implant Supporting a Crown with a Premature Contact. J. Med. Assoc. Thail. 2009, 92, 1336-1344.

28. Valente, F.; Scarano, A.; Murmura, G.; Varvara, G.; Sinjari, B.; Mandelli, F.; Piattelli, M.; Caputi, S.; Traini, T. Collagen Fibres Orientation in the Bone Matrix around Dental Implants: Does the Implant's Thread Design Play a Role? Int. J. Mol. Sci. 2021, 22, 7860. [CrossRef] [PubMed]

29. Silveira, M.P.M.; Campaner, L.M.; Bottino, M.A.; Nishioka, R.S.; Borges, A.L.S.; Tribst, J.P.M. Influence of the dental implant number and load direction on stress distribution in a 3-unit implant-supported fixed dental prosthesis. Dent. Med. Probl. 2021, 58, 69-74. [CrossRef] [PubMed]

30. Tribst, J.P.M.; Dal Piva, A.M.D.O.; Gonçalves, N.I.E.; Borges, A.L.S.; Bottino, M.A.; Kleverlaan, C.J. Polymerization shrinkage and push-out bond strength of different composite resins for sealing the screw-access hole on implant-supported crowns. J. Adhes. Dent. 2020, 22, 523-530. [PubMed]

31. Bottino, M.A.; de Oliveira, F.R.; Sabino, C.F.; Dinato, J.C.; Silva-Concílio, L.R.; Tribst, J.P.M. Survival Rate and Deformation of External Hexagon Implants with One-Piece Zirconia Crowns. Metals 2021, 11, 1068. [CrossRef] 